\title{
Population and Poverty Nexus in Pakistan
}

\author{
Muhammad Afzal ${ }^{1}$ \\ Samia Awais ${ }^{2}$
}

\begin{abstract}
Pakistan has one of the highest population growth rates in the world. Rapid population growth is the bone of contention as well as the crux of the problems. 80 million people live below the poverty line. Macroeconomic instability, rising absolute and relative poverty and worsening income inequalities are the direct as well as indirect result of the high population growth. Population pressures are threatening land, forests and water resources. Improvement in operation and implementation of the family planning programme, increase in female literacy rate and enhancement of women social status can help reduce population growth and poverty. The demographic window argument is far-fetched and irrelevant to Pakistan. $A$ redistribution of agriculture land through radical changes in land tenure coupled with corresponding changes in rural institutions that direct production are expected to help reduce poverty significantly and also improve socio-economic scene in the rural areas. A sound population policy coupled with political motivation can take care of rapid population growth and poverty.
\end{abstract}

Keywords: Population, poverty, developing countries, Human Development Index

\section{Introduction}

According to United Nations estimates world population would exceed 9.1 billion by the year 2050 before reaching the 11 billion mark by 2200 . Over $90 \%$ of that population will live in the developing countries. Such unprecedented increase in population can have serious consequences for the well being of the humanity (Todaro \& Smith, 2012).

In Pakistan because of low literacy rate particularly among females, common man is unaware of the alarming and harmful consequences of rapid population growth. Religious teachings, preference for son, lack of access to family planning methods both due to low per capita income and education, and cultural factors appear to be the potential factors that have caused fast growth of population that culminate into several social and economic problems. Growing demand for houses, education, transport, and health, deteriorating law and order situation, energy crisis, environmental degradation, traffic density and fatal accidents coupled with low saving and low investment culminating in low per capita income and lacklustre economic growth and development are the most conspicuous problems associated mainly with unbridled population growth. Rapid growth of population is one of the most potential sources of escalating poverty in Pakistan.

According to Government of Pakistan statistics (2011-2012) the massive social disruption caused by 2005 earthquake, intensification of war on terror since 2007, devastating floods

\footnotetext{
${ }^{1}$ Dr. Muhammad Afzal is Professor, Department of Economics, Preston University, Islamabad, profafzal@gmail.com

${ }^{2}$ Samia Awais, Lecturer, Department of Management Sciences, COMSATS Institute of Information Technology, Islamabad.

\begin{tabular}{llll|l}
\hline JISR-MSSE & Volume 12 & Number 2 & July-December 2014 & 63
\end{tabular}
}


and heavy rains of 2010 and 2011 and persistent hike in food and oil prices in recent years coupled with slower pace of economic growth has seriously affected poverty and income distribution.

Pakistan's last population census was conducted in 1998 and working on 2011 census is in the offing. Since 1999-2000, population projections for the 10th Five Year Plan 2010-15 have been revised. Pakistan's population in mid-2011 is estimated at 177.1 million 1 to 2.1 percent higher than last year. It was only 32.5 million in $1947 ; 144.6$ million more people have been added during the last 64 years. Pakistan has one of the highest population growth rates in the world. Population growth has decelerated from 3.06 percent in 1981 to 2.07 percent in 2011 (GoP 2010-11, p.151).

Poverty is a multifaceted phenomenon and many factors account for the poverty incidence. Poverty cannot be explained exclusively on the basis of rapid population growth alone. High inflation, low employment opportunities, lackluster economic growth, income and wealth inequalities, worst governance, unbridled corruption, lack of education, and poor health facilities are the major causes of poverty in Pakistan. However, rapid population growth and high fertility rates, especially among the poor make poverty worse and make it difficult for the government to take care of it. Poverty manifests in many ways.

When poverty is pervasive, the poor have no access to credit, clean drinking water and adequate sanitation, education and health facilities, comfortable transport, and representation in the corridors of power. They have many children since the rich get richer; the poor get children as a source of old-age financial security. Poor have meager incomes and low levels of living that result in underprivileged health, nutrition, and education facilities, and thus lesser economic productivity that leads to slow economic and income growth. According to Todaro and Smith (2012), women constitute a substantial majority of the poor population. If the lives of the inhabitants of the poorest communities throughout the developing world are compared, it may transpire that practically everywhere, women and children experience the harshest deprivation. They are most probable to be poor and malnourished and less likely to benefit from medical services, clean water, sanitation, and other facilities.

\section{Population Scenario in Pakistan}

Using data on 80 developing and developed countries, Mapa and Balisacan (2004) explored the relationship between population and poverty. They have concluded that total population growth exerts a negative and significant effect on economic growth while trade openness, good governance, working-age population growth, and life expectancy at birth have positive and significant effects on economic growth.

For many years, development economists have debated the seriousness of the consequences of rapid population growth. Those who are of the view that rapid population growth is not a real problem have offered three arguments: (a) population growth is not a problem but there are other issues (b) population growth reduction is a conspiracy of the capitalists' countries to keep developing countries in their dependence (c) for many developing countries population growth is desirable. These arguments may carry some weight; however, these are weighed against the counter arguments of those who believe that rapid population growth is a real problem for LDCs (less developed countries). One view is that all of the world's economic and social problems result from excessive population growth (Afzal 2009).

\begin{tabular}{l|llll}
\hline 64 & July-December 2014 & Volume 12 & Number 2 & JISR-MSSE
\end{tabular}


Rapid population growth lowers per capita income growth in most LDCs. The poor bears the brunt of the negative effects of population growth. They become landless, face loss of jobs, and the government reduction of expenditure on education and health. It is generally agreed that large family size and low incomes limit the opportunities of parents to educate all their children. High fertility harms the health of mothers and children. Rapid population growth generates food security problem and contributes to environmental degradation in the form of deforestation, soil erosion, unsafe water, air pollution and urban congestion. Rapid population growth is the major factor causing increasing international migration both legal and illegal (Todaro \& Smith, 2012).

Todaro and Smith ( 2012 ) added that since the publication of Thomas Malthus Essay on the Principle of Population in 1798 development economists and policy makers have devoted a good deal of effort to address the problem of population growth. The Malthusian population trap is the well-known theory of the relationship between population growth and economic development. According to this theory, human population grows geometrically while means of subsistence grow arithmetically being subject to the law of diminishing returns. Unfortunately, it is based on a number of simplistic assumptions and hypotheses that do not stand the test of empirical verification. However, on the basis of Malthus theory development economists have asserted that rapid population growth retards economic development since it directly affects the employment situation due to fast growing population.

Bloom and Canning (2001) are among the few who explored the effect of the demographic transition on economic growth. They argue that it is possible that the interaction of economic growth with population dynamics can result in a poverty trap. A study (Dao 2012) has shown that high population growth rates in developing countries since the middle of the twentieth century have had little effect on per capita GDP growth. However, according to Dao (2012) the current consensus is that as more data become available, rapid population growth has exerted a significant negative effect on economic growth in the developing countries.

Citing literature, Dao (2012) reports that recent experience of fertility decline in developing countries in Asia and Latin America has reduced a country's dependency ratio, leading to the potential for faster economic growth through higher saving and investment levels in both physical and human capital (such as higher educational attainment and training for young workers). The decline in fertility in this region will eventually lead to an increase in its oldage dependency ratio as is the case for both Europe and Japan. Population ageing thus may be exercising a negative impact on economic growth.

Afzal (2009) concludes that rapid population growth is a genuine problem in Pakistan because it contributes to lower investment growth and diminishes the savings rate. Highly significant and negative coefficient of population growth demonstrates that population growth is a real problem in Pakistan. Investment growth will considerably contribute to economic growth which in turn depends on high saving rate. Foreign investment and export promotion are expected to have benign impact on economic growth of Pakistan. Pakistan has the highest dependent population that hinders economic growth. Population growth has become a critical issue that discourages economic development and must be addressed seriously and squarely. Provision of scientific and liberal education in educational institutions and media can make the people think independently and rationally and consequently they will think about reducing family size. 
Pakistan was the $13^{\text {th }}$ most populous country in the world with a population of 32.5 million in 1947. Today, Pakistan is the $6^{\text {th }}$ most populous country in the world with a population of 180 million souls. In 2050, its rank would be $5^{\text {th }}$ far exceeding Bangladesh and Indonesia which ranked 4 and 8 respectively in 2012 (Table 1). Except India, China and Indonesia, Pakistan's projected population will far exceed other Asian countries in 2025 (Table 2).

Table 2 and Table 3 provide a conspicuous disadvantaged position of Pakistan compared with other Asian countries in terms of the given indicators. Pakistan has the highest birth rate; infant mortality rate; total fertility rate and dependency burden and have the lowest contraceptive use and income except Bangladesh. These factors reinforce each other and aggravate population growth and poverty incidence demonstrating close link between poverty and population growth.

Table 1

Most Populous Countries

\begin{tabular}{lcclc}
\hline & $\mathbf{2 0 1 2}$ & & $\mathbf{2 0 5 0}$ & \\
\hline Country & $\begin{array}{c}\text { Population } \\
\text { (millions) }\end{array}$ & Rank & Country & $\begin{array}{c}\text { Population } \\
\text { (millions) }\end{array}$ \\
\hline China & 1350 & 1 & India & 1691 \\
India & 1260 & 2 & China & 1311 \\
USA & 314 & 3 & USA & 423 \\
Indonesia & 241 & 4 & Nigeria & 402 \\
Brazil & 194 & 5 & Pakistan & 314 \\
Pakistan & 180 & 6 & Indonesia & 309 \\
Nigeria & 170 & 7 & Bangladesh & 226 \\
Bangladesh & 153 & 8 & Brazil & 213 \\
Russia & 143 & 9 & Congo & 194 \\
Japan & 128 & 10 & Ethopia & 166 \\
\hline
\end{tabular}

Source: Population Reference Bureau (2012)

Pakistan's population has grown at an average rate of 3\% per annum since 1951 until mid $1980 \mathrm{~s}$ but it slowed to an average rate of $2.6 \%$ per annum during 1986-2000 and since 2001 it is growing at an average rate of almost $2 \%$ per annum. Had Pakistan's population grown at $2 \%$ since 1960, Pakistan's per capita income would have been Rs. 64366 as against Rs. 43748. During the five decades 1950- 2001, Pakistan's population has increased 4.3 times, whereas the population of South Korea increased only 2.4 times. Over the same period, per capita income in Pakistan increased by only five times from $\$ 79$ in 1950 to $\$ 503$ in 2001, whereas in South Korea it increased by 129 times from $\$ 82$ in 1950 to $\$ 10550$ in 2001 (GOP 2004-05). 
Table 2

Pakistan and Asian Countries: Demographic Indicators

\begin{tabular}{|c|c|c|c|c|c|c|}
\hline Country & $\begin{array}{l}\text { Population } \\
\text { (millions) } \\
\text { Mid-2012 }\end{array}$ & $\begin{array}{l}\text { Projected } \\
\text { population } \\
\text { (millions) } \\
2025\end{array}$ & $\begin{array}{c}\text { Projected } \\
\text { Population } \\
\text { (millions) } \\
\text { Mid-2050 }\end{array}$ & $\begin{array}{c}\text { Births per } \\
1000 \\
\text { population }\end{array}$ & $\begin{array}{c}\text { Deaths per } \\
1000 \\
\text { population }\end{array}$ & $\begin{array}{c}\text { Infant } \\
\text { Mortality } \\
\text { Rate }\end{array}$ \\
\hline Pakistan & 180.4 & 229.6 & 314.3 & 28 & 8 & 68 \\
\hline India & $1,259.7$ & 1458.2 & 1691.1 & 22 & 7 & 47 \\
\hline China & 1350.4 & 1402.1 & 1310.7 & 12 & 7 & 17 \\
\hline Bangladesh & 153.0 & 183.2 & 226.3 & 23 & 6 & 43 \\
\hline Indonesia & 241.0 & 273.2 & 309.4 & 19 & 6 & 29 \\
\hline Philippines & 96.2 & 117.8 & 154.5 & 25 & 6 & 22 \\
\hline Vietnam & 89.0 & 101.6 & 110.2 & 17 & 7 & 16 \\
\hline Thailand & 70.0 & 72.9 & 71.0 & 12 & 7 & 12 \\
\hline Japan & 128.0 & 119.8 & 95.5 & 9 & 10 & 2.3 \\
\hline Korea, south & 48.9 & 50.9 & 47.2 & 10 & 5 & 3.2 \\
\hline
\end{tabular}

Source: Population Reference Bureau (2012)

Table 3

Pakistan and Asian Countries: Dependency Burden and Income

\begin{tabular}{|c|c|c|c|c|c|}
\hline Country & $\begin{array}{l}\text { Total } \\
\text { fertility } \\
\text { rate }\end{array}$ & $\begin{array}{c}\text { Life } \\
\text { Expectanc } \\
\text { y at birth }\end{array}$ & $\begin{array}{l}\text { below15 } \\
\text { years* }\end{array}$ & $\begin{array}{c}\text { GNI PPP } \\
\text { per } \\
\text { capita(us\$) } \\
2010\end{array}$ & $\begin{array}{c}\text { Contraceptive } \\
\text { use }\end{array}$ \\
\hline Pakistan & 3.6 & 65 & 35 & 2790 & 27 \\
\hline India & 2.5 & 65 & 31 & 3400 & 54 \\
\hline China & 1.5 & 75 & 16 & 7640 & 85 \\
\hline Bangladesh & 2.3 & 69 & 31 & 1810 & 61 \\
\hline Indonesia & 2.3 & 72 & 27 & 4200 & 61 \\
\hline Philippines & 3.2 & 69 & 35 & 3980 & 51 \\
\hline Vietnam & 2.0 & 73 & 24 & 3070 & 78 \\
\hline Thailand & 1.6 & 74 & 21 & 8190 & 80 \\
\hline Japan & 1.4 & 83 & 13 & 34,610 & 54 \\
\hline Korea, south & 1.2 & 81 & 16 & 29,110 & 80 \\
\hline
\end{tabular}

Source: Population Reference Bureau (2012), * \% of population

\section{Poverty Status}

There is huge literature on different aspects of poverty in Pakistan. During 1960-2010 PIDE (Pakistan Institute of Development Economics) alone conducted 110 studies. Nasim (2012) has done a critical review of poverty studies that covers all important facets of poverty. However, no link between poverty and population has been examined. Studies conducted on

\begin{tabular}{lll|l}
\hline JISR-MSSE & Volume 12 & Number 2 & July-December 2014
\end{tabular}


poverty in Pakistan have remained over-concerned with measuring the magnitude of poverty using different methodologies and data sets. Therefore, the paper examines the relationship between population growth and poverty in Pakistan using diverse set of information.

Table 4

Poverty Rates at International Poverty Lines

\begin{tabular}{|c|c|c|c|c|c|c|}
\hline Country & $\begin{array}{c}\text { Local } \\
\text { currency } \\
(2005)< \\
\text { \$2per day } \\
\text { earnings }\end{array}$ & $\begin{array}{c}\text { \%Populati } \\
\text { on } \\
\text { (Year) }< \\
\$ 2 \text { per day } \\
\text { earnings }\end{array}$ & $\begin{array}{c}\text { \%Populati } \\
\text { on } \\
\text { (Year) }<\$ 2 \\
\text { per day } \\
\text { earnings }\end{array}$ & $\begin{array}{c}\text { \%Populati } \\
\text { on } \\
\text { (Year) }< \\
\$ 1.25 \text { per } \\
\text { day } \\
\text { earnings }\end{array}$ & $\begin{array}{c}\text { \%Populati } \\
\text { on } \\
\text { (Year) }< \\
\$ 1.25 \text { per } \\
\text { day } \\
\text { earnings }\end{array}$ & $\begin{array}{c}\text { Local } \\
\text { currency } \\
(2005)< \\
\$ 1.25 \text { per } \\
\text { day } \\
\text { earnings }\end{array}$ \\
\hline \multirow[t]{2}{*}{ Pakistan } & 41.4 & 61 & 60.2 & 22.6 & 21 & 25.9 \\
\hline & & -2006 & -2008 & -2006 & -2008 & \\
\hline \multirow[t]{2}{*}{ India } & 31.2 & 75.6 & 68.7 & 41.6 & 32.7 & 19.5 \\
\hline & & -2005 & -2010 & -2005 & -2010 & \\
\hline \multirow[t]{2}{*}{ China } & 8.2 & 36.9 & 29.8 & 16.3 & 13.1 & 5.1 \\
\hline & & -2005 & -2008 & -2005 & -2008 & \\
\hline \multirow[t]{2}{*}{ Bangladesh } & 51 & 80.3 & 76.5 & 50.5 & 43.3 & 31.9 \\
\hline & & -2005 & -2010 & -2005 & -2010 & \\
\hline \multirow[t]{2}{*}{ Indonesia } & - & 52.7 & 46.1 & 20.4 & 18.1 & - \\
\hline & & -2009 & -2010 & -2009 & -2010 & \\
\hline \multirow[t]{2}{*}{ Philippines } & 48.4 & 45 & 41.5 & 22.6 & 18.4 & 30.2 \\
\hline & & -2006 & -2009 & -2006 & -2009 & \\
\hline \multirow[t]{2}{*}{ Vietnam } & - & 48.1 & 43.4 & 21.4 & 16.9 & - \\
\hline & & -2006 & -2008 & -2006 & -2008 & \\
\hline \multirow[t]{2}{*}{ Thailand } & 34.9 & 5 & 4.6 & $<2$ & $<2$ & 21.8 \\
\hline & & -2008 & -2009 & -2008 & -2008 & \\
\hline \multirow[t]{2}{*}{ Nigeria } & 157.2 & 83.1 & 84.5 & 63.1 & 68 & 98.2 \\
\hline & & -2004 & -2010 & -2004 & -2010 & \\
\hline \multirow[t]{2}{*}{ Sri Lanka } & 80.1 & 39.7 & 29.1 & 14 & 7 & 50 \\
\hline & & -2002 & -2007 & -2002 & -2007 & \\
\hline
\end{tabular}

Source: Population Reference Bureau (2012)

Pakistan fares well compared with India and Bangladesh for population that earns less than $\$ 2$ per day (Table 4). However, in terms of local currency, Pakistan has smaller population than Bangladesh and Philippines. Nigeria has the highest percentage of population in local currency for both less than $\$ 1$ and less than $\$ 2$ per day earnings. In terms of international poverty line measured in dollars, Pakistan poverty situation is better than India, Bangladesh and Nigeria and does well in local currency compared to Bangladesh and Nigeria. These data do not show the poverty situation in Pakistan beyond 2008. Economy had been doing well up to the end of 2007 and therefore, poverty incidence is not worse vis-à-vis India and Bangladesh. However, due to low economic growth, rising inflation and high unemployment, the incidence of poverty has increased considerably as mentioned below. 
Economists argue based on population-poverty cycle theory that rapid population growth gives way to negative economic consequences and this should be a real concern for the developing countries because population growth retards hopeful prospects. More recent evidence on the incidence of poverty indicates that poverty that declined in 1970s and 1980s increased in 1990s that have adversely affected the poor families demand for education and the health and housing conditions have also deteriorated.The declining trend in poverty as seen in the country during the 1970s, 1980s and early 2000s received a setback in the post 2007 years due to poor federal policies, bad governance and unprecedented corruption. As of 2009, Pakistan's Human Development Index (HDI) is 0.572, higher than that of nearby Bangladesh's 0.543, Pakistan's HDI still stands lower than that of neighbouring India's at 0.612. Wealth distribution in Pakistan is highly uneven, with the top $10 \%$ of the population earning $27.6 \%$ and the bottom $10 \%$ earning only 4.1 of the income. According to the United Nations Human Development Report, Pakistan's human development indicators, especially those for women, fall significantly below those of countries with comparable levels of percapita income. Pakistan also has a higher infant mortality rate (88 per 1000) than the South Asian average (83 per 1000).

The links between malnutrition, ill health and poverty are well known. Disease contributes to poverty due to the costs of illness and reduces earning capacity during and after illness. Good health is a first step towards prosperity and reduction of poverty. Food security is a national priority. The Government of Pakistan (2011-12) has reported that about 32 percent children under the age of five years and 15 percent mothers are underweight. About 30 percent babies have low-birth weight, reflecting the poor nutritional status of mothers. The most recent data on health performance of other South Asian countries suggest that Pakistan lags behind in infant mortality rate (at 68 per 1000 live births) and the under 5 years mortality rate (at 86.5 per 1000 live births). These indicators continue to remain high mainly on account of unhealthy dietary habits, water borne diseases, malnutrition and rapid population growth. If Pakistan's population planning indicators are compared with its immediate neighbours and with some Muslim countries, it is crystal clear that Pakistan's indicators are poorly comparable with regional or Muslim countries. More efforts are needed to improve these indicators.

Arif and Farooq (2012) have analyzed the dynamics of rural poverty in Pakistan. They used the three waves of panel household survey carried out by PIDE in 2001, 2004 and 2010. They have reported three major conclusions. First, for a longer period say last 10 years, the proportion of population that ever lived below the poverty line during the period is much larger $(51 \%)$ than the one from the cross-sectional survey datasets. Second, only a small proportion of population remained in the state of poverty for 10 years. This means that when a household experiences a decline in its well-being, it manages to improve its living standard. Third, moving into and out of poverty is a common phenomenon in rural Pakistan that directly depresses the desired status of 'never poor.

Multivariate analysis by Arif and Farooq (2012) reveals that demographic variables, household size and dependency ratio have a significant positive association with chronic poverty as well as falling into poverty. Economic variables (the ownership of land and livestock, housing structure and availability of room) have a significant and negative association with the chronic poverty. Besides the inflation, natural shocks are likely to keep households either in chronic 
poverty or push them into the state of poverty. They add that a change in both the demographic and economic factors at the household level affects the poverty dynamics. The demographic burden increases the likelihood of falling into poverty while a positive change in economic status improves the households' well-being.

\section{Population and Poverty}

Rapid population growth in Pakistan has been alarming. Pakistan though ranked 6th in size adds more than twice as many peoples to the absolute growth of world population than USA which ranks third. This situation has created insurmountable and complicated social, economic and political problems that have negative impact on the macroeconomic stability. Ethnicstrife and deteriorating law and order situation, agonizing problems of housing, expensive educational and health facilities, traffic density and congestion, frequent and fatal accidents have made the common man life miserable and unsustainable.

These factors have collectively contributed to escalating cost of living that breeds macroeconomic instability, on one hand and on other hand, rising absolute and relative poverty and worsening income inequalities are the direct as well as indirect result of the aforesaid factors. Rapid population growth and urbanisation have led to the increased levels of industrial waste, vehicle emissions, and water and air pollution culminating in serious health problems. Thus rapid population growth is the bone of contention as well as crux of the problems. Socioeconomic conditions would be better off if population were to grow slowly that would have also resulted in a better social and economic condition (Afzal 2009).

Agriculture is the mainstay of Pakistan's economy. The arable and almost all crops in Pakistan rely on irrigation. Supplies of both arable land and fresh water are unlikely to increase, calling into question Pakistan's ability to feed itself. Population pressures are threatening land, forests and water resources. The size of land holdings has decreased due to population growth, inadequate land reforms and inheritance patterns. Before the middle of this century, Pakistan is projected to face a scarcity of arable land with even less land available per person than in China. Limited renewable fresh water supplies may be the biggest obstacle to increasing Pakistan's food supply (Rosen and Conly 1995).

A grim and pessimistic situation and projections of the fate of agriculture presented 20 years back has not improved. The situation has gotten worse in recent years. Pakistan's agriculture still faces the shortage of water supply, energy crisis, input-output price differential, rising cost of agriculture inputs, escalation in food prices etc. Agricultural land is constantly being turned into residential colonies. Because of successive distribution of land among heirs and mushroom growth of residential colonies has adversely affected the cultivable land and thus lowering agricultural productivity. Rapid population growth has led to the large demand for housing colonies. 
Family planning program because of lack of rational approach to social and cultural obstacles has not achieved enviable success. Absolute poverty, lower woman status and low levels of living provide the economic rationale for large families and rapidly increasing population. Provisions of scientific and liberal education though print and electronic media would persuade people to have smaller families. Sex ratio has declined over the years. It declined from 115 in 1972 to 111 in 1981, and 107 in 2011 implying that the frequency of females has followed an increasing trend. This is distressing and painful and is expected to fall further that will intensify social, psychological and economic problems for parents as well as females. There seems no solution to this agonizing problem in the short-run. Polygamy will make the confusion worse confounded. It is extremely difficult to adopt the western social system and values. Improvement in operation and implementation of the family planning programme, increase in female literacy rate and enhancement of women social status appear to be an agreeable solution.

There is a general view that highly skewed distribution of land in Pakistan is a potential cause of widespread poverty in rural areas (Anwar et al., 2004). They have reported that the prevalence of poverty was found to be highest among landless at $54.89 \%$ across rural areas. Not only the poverty-gap but also the degree of inequality among the landless households was significant. Since the inception of the country, population growth has been substantial. Its momentum has slightly declined since mid-1980s. Resources that could be used for productive purposes are diverted to satisfy the consumption needs that have adversely affected the national saving rate. Consequently for achieving the goal of rapid economic development and to transform the predominant agrarian economy, Pakistan had to seek external financial assistance that has burdened the country with heavy debt.

Over the years rural-urban composition has undergone noticeable trend (Table 5). Significant reduction in rural population and more than three times increase in population density at the Pakistan level not only indicates high population growth but also rapid migration from rural areas to urban centers where employment opportunities have been concentrated because population density is a function of employment opportunities. Both relative and absolute size of the large cities notably Karachi, Lahore, Peshawar and other cities has increased alarmingly because rapid population growth has put enormous pressure on these Cities. There is an urgent need that the rampant growth of each City is delimited otherwise this Cites would become ungovernable.

Dramatic social changes have led to rapid urbanization and the emergence of megacities. During 1990-2003, Pakistan sustained its historical lead as the second most urbanized nation in South Asia with city dwellers making up 36\% of its population. Furthermore, 50\% of Pakistanis now reside in towns of 5,000 people or more. Changes in the age structure are another important indicator of the composition of the population of a country. Population falling in the age group $0-9$ and $60 \&$ above constitutes the dependent population. The dependent population declined from $38.3 \%$ in 1972 and 1981 to $33 \%$ in 1990 but increased to $36.1 \%$ in 1998 , but declined to $27.36 \%$ and $26.32 \%$ in 2010 and in 2015 respectively (Table 6). The dependent population hinders economic growth because it is supported financially by the active labor force and living standard falls that adversely affects the productive efficiency of the working population. Therefore, moderate population growth will help reduce the dependency burden. 
The younger population (10-19) constitutes more than $20 \%$ of the population in the age groups. With the exception in rural areas and poor families in urban centres, this may also be treated as dependent population because this age group is busy in acquiring education that is financed by the parents. If this group is also added the dependent population rises to more than $60 \%$. After completing education, this group adds to the army of unemployed youth that results in social and economic problems. Since low income families members marry in the early age, population growth increases that in turn escalate poverty.

According to Government of Pakistan statistics (2011-12, p. 163 ) the available projections of the population by age categories indicate that those below 30 years of age will constitute more than 53 percent of the total population by 2030. Countries, like Pakistan, having a very young age structure are more likely to have large dependent population which puts a considerable stress on the economy. This higher percentage has a dual impact on the country's future economic and social wellbeing. The growing youth population will only add marginally to the productive resources of the country but will put a large burden on health, education and decent jobs, if they are not trained properly. This will worsen both the economic and social situation.

Pakistan's rapid population growth has a direct bearing on the labor market that has aggravated the employment situation. There is a close association between rapid population growth and poverty. With stagnant or declining employment opportunities, a persistent increase in population would result in increasing relative and absolute poverty. The threat of the socalled demographic winter (aging, etc.) is indefensibly overstated for the Pakistan and is used as a forceful argument against a rational population policy. This argument applies more to USA, Russia, Europe and Japan than fast growing population countries like Pakistan.

Table 5

Population Growth- Rural and Urban Distribution

\begin{tabular}{lcccc}
\hline Year & Population & Growth & Rural \% & Urban \\
1911 & 19.382 & 1.6 & 91.3 & 8.7 \\
1921 & 21.109 & 0.9 & 90.3 & 9.7 \\
1931 & 23.542 & 1.1 & 88.2 & 11.8 \\
1951 & 33.74 & 1.8 & 82.2 & 17.8 \\
1961 & 42.88 & 2.4 & 77.5 & 22.5 \\
1972 & 65.309 & 3.7 & 74.6 & 25.4 \\
1981 & 84.254 & 3.1 & 71.7 & 28.3 \\
1992 & 115.54 & 2.6 & 71.60 & 28.40 \\
2000 & 139.96 & 2.3 & 53.87 & 46.13 \\
2004 & 152.53 & 2.2 & 47.59 & 52.41 \\
2010 & 173593 & 2.05 & 33.68 & 66.32 \\
\hline
\end{tabular}

Source: GOP, Economic Survey (various issues)

\begin{tabular}{l|llll}
\hline 72 & July-December 2014 & Volume 12 & Number 2 & JISR-MSSE
\end{tabular}


Table 6

Percentage Distribution of Population by Age

\begin{tabular}{lcccccc}
\hline Age Group & 1972 & 1981 & 1990 & 1998 & 2010 & 2015 \\
$0-4$ & 15.1 & 15.4 & 15.6 & 14.84 & 13.10 & 12.38 \\
$5-9$ & 16.2 & 16.0 & 13.9 & 15.69 & 12.08 & 11.60 \\
$10-14$ & 12.5 & 13.2 & 11.0 & 12.71 & 12.09 & 10.91 \\
$15-19$ & 8.5 & 9.4 & 9.4 & 10.40 & 11.90 & 10.94 \\
$20-24$ & 7.3 & 7.8 & 8.7 & 9.00 & 10.31 & 10.77 \\
$25-29$ & 7.4 & 6.7 & 7.7 & 7.39 & 8.87 & 9.31 \\
$30-34$ & 6.3 & 5.6 & 6.5 & 6.24 & 7.49 & 8.00 \\
$35-39$ & 5.3 & 5.1 & 5.9 & 4.79 & 6.28 & 6.74 \\
$40-44$ & 4.9 & 4.7 & 5.1 & 4.46 & 5.17 & 5.63 \\
$45-49$ & 3.8 & 3.7 & 4.1 & 3.54 & 4.25 & 4.62 \\
$50-54$ & 3.7 & 3.6 & 3.4 & 3.22 & 3.48 & 3.74 \\
$55-59$ & 1.9 & 2.0 & 2.8 & 2.16 & 2.80 & 3.01 \\
$60 \&$ above & 7.0 & 6.9 & 3.5 & 5.56 & 2.18 & 2.34 \\
\hline
\end{tabular}

Source: GOP, Economic Survey (various issues)

Pakistan's problems with militancy, a fragile economy and natural disasters such as the 2010 floods have often been discussed at length, but an even greater threat may be posed by the sheer numbers of people in the country has not received adequate attention. According to official figures, the projected population for 2015 is 191 million. Malnutrition rates are high and are linked to 50 per cent of infant and child deaths; there is one doctor for every 1,183 people; and the literacy rate of 57 per cent is among the lowest in South Asia. There is now increasing evidence that investments, among others, in education, health, including reproductive health, women's empowerment and slower population growth contribute towards poverty reduction. In general, it has also been found that where there is rapid population growth and high fertility rates, poverty incidence is also highest. Many women would like to practice birth control, but their husbands dislike the idea. People believe large families mean more earning hands; but they do not realize they also mean more eating mouths.

The fast growth of population is also putting pressure on agricultural land; there were 4.1 million agricultural farms in 1980. Due to fragmentation, their number has increased to 6.2 million in 2000. Pakistan's rapid population growth is one of the main impediments in the way of government efforts for achieving the overall national development goals and sustained socio-economic growth. It is imperative to stabilize population so that burden on existing infrastructure is reduced and the reward of economic growth is not diluted by rapid increase in population.

According to Benazir Income Support Programme (BISP) based on a door-to-door survey, $45.7 \%$ of the entire population is living under the poverty line. These results negate the outcome of another official survey which calculated incidence of poverty at $12 \%$. BISP Chairperson Farzana Raja told the National Assembly Standing Committee on Finance that 
80 million people live below the poverty line. The survey did not include Federally Administrated Tribal Areas where it was delayed because of the security situation. Pakistan Social and Living Standards Measurement (PSLM) Survey 2010-11, shows that the incidence of poverty has declined from $17.2 \%$ in 2008 to slightly over $12 \%$ in 2011 . In $2010-11$, the estimated population was 175.3 million and around 21.5 million people were living in abject poverty. The government is reluctant to officially announce the PSLM survey based results. Experts argue that a drop in poverty is impossible when there is an average job growth of $2.6 \%$ in the last four years against the requirement of $8 \%$ and inflation has stayed in double-digits for the fifth consecutive year.

\section{Conclusion}

The rapid population growth is the bone of contention as well as crux of the problems. High population growth is the most potential source of ethnic-strife, deteriorating law and order situation, agonizing problems of housing, expensive educational and health facilities, traffic density and congestion, frequent and fatal accidents. Macroeconomic instability, rising absolute and relative poverty and worsening income inequalities are the direct as well as indirect result of the aforesaid factors. Population pressures are threatening land, forests and water resources. Improvement in operation and implementation of the family planning programme, increase in female literacy rate and enhancement of women social status appear to be an agreeable solution. There is a close association between rapid population growth and poverty. With stagnant or falling employment opportunities, a relentless increase in population would result in increasing relative and absolute poverty.

Poverty can be taken care of if the economy succeeds in achieving a respectable economic growth of more than $6 \%$. Plans to reduce population growth over the years do not seem to have succeeded. Therefore, population growth has become a critical issue that discourages economic development and must be addressed seriously and squarely in order that the country has respectable economic growth. Provision of scientific and liberal education in educational institutions and media can make the people think independently and rationally. When people start thinking themselves, they will think about rationalizing family size.

A sound population policy that aims at checking the rapid population growth coupled with good governance and a strong family planning programme, liberal and scientific education in educational institutions and media; sound fiscal and monetary policies will collectively take care of poverty in Pakistan. The so-called demographic window argument is far-fetched and irrelevant to Pakistan. All this will be made possible if there is strong political will and determination to carry out the afore-mentioned policies. 


\section{References}

Afzal, M. (2009). Population growth and economic development in Pakistan, Open Demography Journal, 2, 1-7.

Anwar, Talat, Sarfaraz. K. Qureshi, and Hamad Ali (2004). Landlessness and rural poverty in Pakistan. The Pakistan Development Review, 43(4), 855-874.

Arif G. M. and Shujaat Farooq (2012). Dynamics of rural poverty in Pakistan: evidence from three waves of the panel survey, Islamabad, Pakistan Institute of Development Economics.

Bloom, D. \& D. Canning (2001). Cumulative causality, economic growth, and the demographic transition, in N. Birdsall, A.C. Kelley and S. Sinding (eds.), Population Matters: Demographic Change, Economic Growth, and Poverty in the Developing World, Oxford: Oxford University Press.

Dao, M. Q. (2012). Population and economic growth in developing countries, International Journal of Academic Research in Business and Social Sciences, 2(1), 6-17.

Population Reference Bureau, (2012). World Population Data Sheet, New York Government of Pakistan, Economic Survey (various issues), Islamabad, Ministry of Finance, Economic Advisor Wing.

Mapa, D. S., \& Balisacan, A. M. (2004). Quantifying the impact of population on economic growth and poverty: The Philippines in an Asian Context', Paper presented at the 9thConvention of the East Asian Economic Association, 13-14 November, Hong Kong.

Nasim, S. M. (2012). A Review of Studies on Poverty in Pakistan: Origin, Evolution, Themetic Content and Future Directions, History of PIDE Series -6, Islamabad, Pakistan Institute of Development Economics.

Population Reference Bureau (2012). World Population Data Sheet, Washington, D.C

Rosen, J. E., \& Shanti R. C. (1995), Pakistan's Population Program: The Challenges Ahead, Country Study series no. 3, Population Action International, Washington D.C.

Todaro, M. P., \& Stephen, C. S. (2012). Economic Development, (11th Ed.). Singapore, Pearson Education World Bank. World Development Indicators, 


\begin{tabular}{l}
-1 \\
\\
$-\ldots$. \\
\hline
\end{tabular}

